\title{
Variability in growth rates of juvenile fishes in different estuarine habitats
}

\author{
Susan M. Sogard* \\ Marine Field Station, Institute of Marine and Coastal Sciences, Rutgers University, Great Bay Boulevard, Tuckerton, \\ New Jersey 08087, USA
}

\begin{abstract}
Estuaries are vital nursery grounds for many marine fishes. During initial estuarine residence, juvenile fishes presumably benefit greatly from rapid growth, which can diminish susceptibility to size-selective predators. To measure the degree of variability in growth rates across different estuarine sites and habitats, I conducted caging experiments with 3 species (Pseudopleuronectes americanus, Tautoga onitis, and Gobiosoma bosci) at 4 sites in New Jersey, USA, estuaries. Two sites were in an estuary with dense eelgrass Zostera marina beds (Little Egg Harbor) and 2 were in an estuary lacking eelgrass but supporting patchy accumulations of the macroalgae Ulva lactuca (Great Bay). Experiments were conducted in vegetated (either Zostera or Ulva) and unvegetated habitats at each site. Relative differences in growth rates among the 4 sites and between the 2 habitats were generally maintained across experiments within species, suggesting a consistency in foraging value. For all 3 species, growth was highest at a Great Bay site and generally lowest at a Little Egg Harbor site. The presence of vegetation (either Zostera or $U_{V a}$ ) was beneficial to growth only for $T$ onitis. Observed patterns in water temperature, sediment structure, and food availability were potential factors effecting the observed differences in growth rates. Natural densities of the 3 fish species were quantified and compared to the results of growth experiments to determine if there were trade-offs between rapid growth and other attributes of habitat quality. $P$. americanus and $T$ onitis were more abundant in areas supporting faster growth, but the complete absence of tautog from unvegetated substrates suggested some degree of habitat avoidance. A clear trade-off between habitat selection and foraging quality occurred for $G$. bosci; gobies were most abundant inside eelgrass beds, which supported the poorest growth rates.
\end{abstract}

\section{INTRODUCTION}

Rapid growth is of critical importance to early juvenile fishes. Mortality rates during this stage are typically very high and are thought to be largely due to predation (Cushing 1974, Houde 1987). With increased size, an individual fish becomes more difficult for a predator to capture and handle. Size-selective predation concentrating on smaller fish prey has been demonstrated for a wide variety of piscivores (e.g. Parker 1971, Healey 1982, Werner et al. 1983, Post \& Evans 1989a). Rapid growth enables a newly settled juvenile to leave the most vulnerable size classes quickly, conferring a selective advantage over slowgrowing conspecifics. For temperate species, fast postsettlement growth may also have a physiological advantage. Post \& Evans (1989b), for example, demon-

\footnotetext{
- Present address: Hatfield Marine Science Center, Oregon State University, Newport, Oregon 97365, USA
}

strated that larger yellow perch were less likely to starve during their first winter. At the population level, variability in growth rates during the early larval and juvenile stages can dramatically influence the size of the subsequent adult population (Houde 1987).

If rapid growth provides a selective advantage and growth rates vary as a function of habitat, we should expect selection for individuals that preferentially choose habitats providing the maximum potential for growth. Interactions with other species, however, may result in compromises or trade-offs in habitat selection. While other interspecific relationships (competition, mutualism, etc.) can also modify habitat selection, much of the experimental work on trade-offs has focused on predation risk. Werner et al. (1983), for example, found that the threat of predation in the 'best' habitat for growth forced juvenile bluegill sunfish Lepomis macrochirus into other habitats, where growth rates were significantly lower Similar compromises in habitat use have been documented in several other fish 
species (e.g. Milinski \& Heller 1978, Cerri \& Fraser 1983, Power 1984, Schmitt \& Holbrook 1985). Concentration of juvenile fishes in protective habitats can further reduce growth rates due to both intraspecific and interspecific competition (Mittelbach 1988).

Along the east coast of the United States, estuaries are vital nursery grounds for juvenile fishes, and vege. tated habitats within estuaries tend to harbor higher densities of many fish species than unvegetated substrates. Most studies documenting the importance of vegetation have concentrated on seagrass (Briggs \& O'Connor 1971, Adams 1976, Orth \& Heck 1980. Weinstein \& Brooks 1983, Heck et al. 1989), but the value of macroalgae habitats such as Ulva lactuca has also been noted (Sogard \& Able 1991). The benefits of vegetated habitats for juvenile fishes are often attributed to enhanced food resources and/or reduced predation rates relative to unvegetated substrates. In a freshwater system, Rozas \& Odum (1988) concluded that submerged aquatic vegetation served both functions for small fishes, with both reduced predation rates and improved foraging profitability compared to unvegetated areas. In experimental studies of predation rates in the field, seagrass and macroalgae provide a protective refuge compared with unvegetated sand (Heck \& Thoman 1981, Wilson et al. 1987, 1989). The value to juvenile fishes of vegetated patches as foraging habitats, relative to unvegetated areas, has not been directly tested.

In the present study I compare in situ growth rates for juveniles of 3 estuarine-dependent fish species (winter flounder Pseudopleuronectes americanus, tautog Tautoga onitis, and naked goby Gobiosoma bosci) in vegetated and unvegetated habitats at 4 sites in New Jersey estuaries. Juveniles of all 3 species are small, demersal, relatively sedentary, and, in the size ranges used in this study, dependent on small-sized prey, primarily amphipods, copepods, and polychaetes (Pearcy 1962, Nero 1976, Festa 1979, Grover 1982). These characteristics make them suitable for manipulative caging experiments.

I used cages to measure short-term growth rates of individual fishes in the field, under baseline conditions in the absence of potential predators and interspecific competitors. Experiments were designed to address the following questions: (1) Does growth vary depending on location in an estuary (i.e. site)? (2) Does growth differ between vegetated and unvegetated habitats? (3) Does the contrast in growth between vegetated and unvegetated habitats depend on site, and thus potentially the vegetation type present?

To determine potential factors influencing growth, I monitored physical parameters and measured prey densities. In addition, to determine if fish were most abundant where growth was optimal, I quantified natural densities of the 3 fish species in the same sites and habitats used for growth experiments. By comparing relative growth rates with natural density patterns, I could infer potential compromises between rapid growth and threats induced by other species, such as increased predation risk.

\section{MATERIALS AND METHODS}

Study sites. Four sites (Fig.1) in New Jersey estuaries were used in this study, 2 in Little Egg Harbor (LEH), which has dense coverage by eelgrass Zostera marina meadows with intermittent patches of bare sand/mud, and 2 in Great Bay (GB), where Zostera is absent but patchy accumulations of sea lettuce Ulva lactuca are temporally common. All 4 sites were subtidal, with depths of 30 to $40 \mathrm{~cm}$ at mean low tide. Fish densities, growth rates, and prey densities were assessed in vegetated (either Zostera or Ulva) and unvegetated habitats at each site, using a 2 -factor (4 sites by 2 habitats) experimental design.

Sediment samples were collected in mid-summer 1989 to determine the percentage of silt/clay (particles $<0.062 \mathrm{~mm}$ ) at each site. Approximately $200 \mathrm{ml}$ of sediment was scraped from the top $\mathrm{cm}$ and dry sieved. Sediment size structure was measured in both vegetated (Zostera) and unvegetated habitats at the LEH sites. At the GB sites sediment samples were collected only from unvegetated areas. Vegetated (UIva) patches were both spatially and temporally variable, with the macroalgae essentially drifting across sandy flats. I assumed that the temporary presence of Ulva would not alter sediment size structure, in contrast to the demonstrated influence of seagrasses on sediments (Marshall \& Lukas 1970).

Water temperatures and salinities. Water temperature was recorded every $20 \mathrm{~min}$ at each site throughout summer 1989, using Ryan Tempmentor recorders placed in PVC housings in the immediate sampling area at each site. The sensor of each probe was positioned at the sediment-water column interface. Because vegetated and unvegetated habitats at each site were at the same depth and within a few meters of each other, I assumed that they would have similar water temperatures. Continuous temperature records were not available for 1988. Salinity was measured with a refractometer in conjunction with each series of fish density estimates.

Fish density estimates. Natural densities of juvenile Pseudopleuronectes americanus, Tautoga onitis, and Gobiosoma bosci were monitored every 2 wk throughout the summers of 1988 and 1989 by quantitative sampling with throw traps. The trap, a $1 \mathrm{~m}^{2}$ open box, was thrown out onto the substrate and all fishes 
Fig. 1. Location of experimental sites in New Jersey estuaries. Sites Little Egg Harbor 1 (LEH1, adjacent to Marshelder Island) and Little Egg Harbor 2 (LEH2, Ham Island) were located in dense natural eelgrass (Zostera marina) beds with interspersed unvegetated patches. Sites Great Bay 1 (GB1, in Little Bay) and Great Bay 2 (GB2, near Little Beach Island) were sand/mud flats with patchy accumulations of sea lettuce macroalgae (Ulva lactuca)

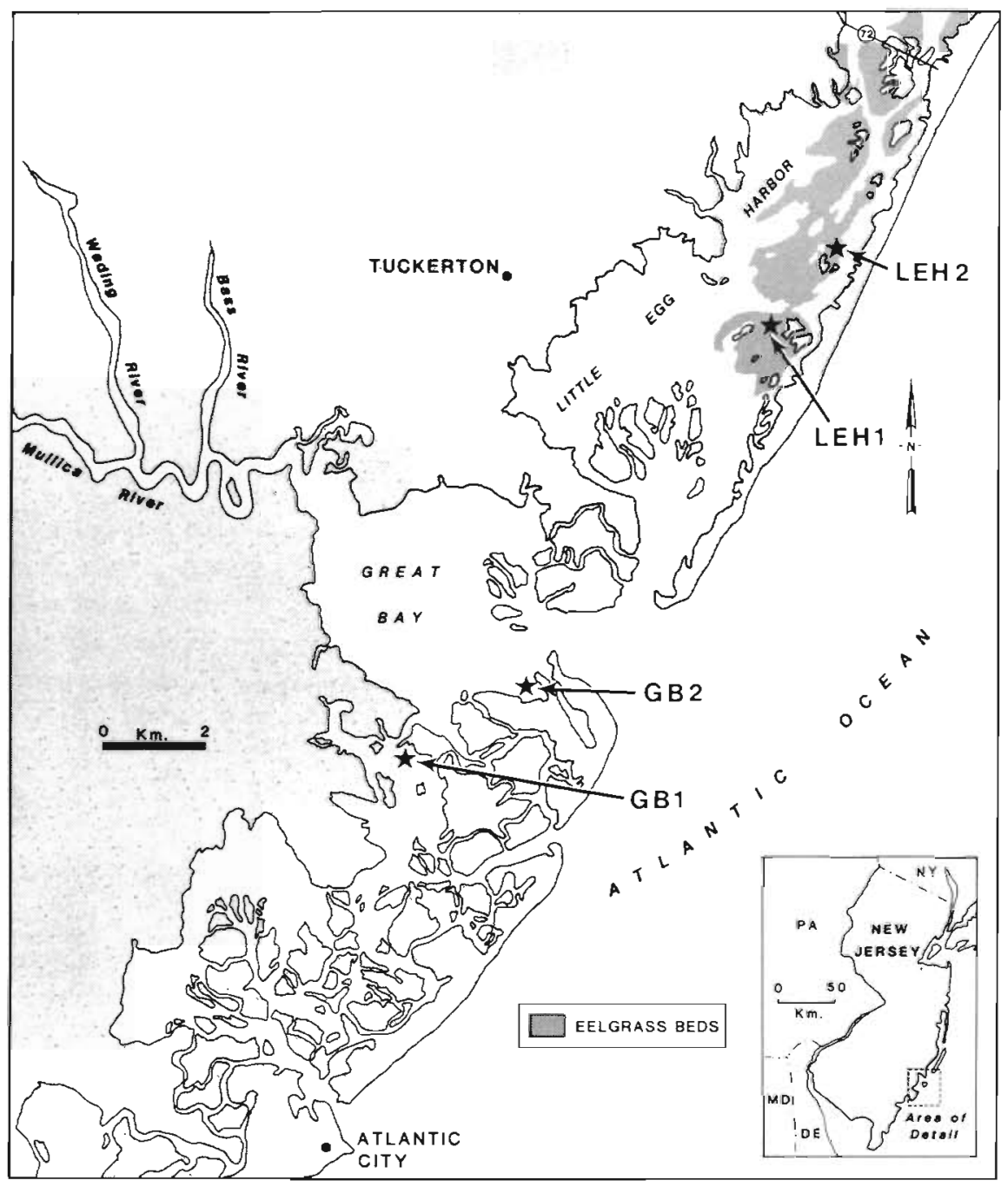

removed with a bar seine until 3 successive passes collected no organisms. In 1988 I collected 4 samples at each site, 2 in vegetated and 2 on unvegetated substrates. In 1989 sampling effort was increased to 6 throw traps per site, 3 in vegetation and 3 in sand. Densities were compared among sites and between habitats (vegetated and unvegetated) with 2-way ANOVAs. Densities were $\log$-transformed $(\log x+1)$ prior to analysis but remained slightly heterogeneous due to zero catches at some sites and habitats.

Vegetation densities were measured in conjunction with each throw trap sample. Methods of vegetation analysis and results are reported in Sogard \& Able (1991) and summarized below in the 'Results' section.

Growth experiments. I conducted 6 growth experiments with Pseudopleuronectes americanus (3 in 1988 and 3 in 1989), 4 experiments with Tautoga onitis in 1988, and 1 experiment with Gobiosoma bosci in 1989 (Table 1). Experiments were conducted with newly settled juveniles near the time of their arrival in the estuaries: in June-July for P. americanus and AugustSeptember for T.onitis and Gobiosoma bosci. Experimental fishes were collected from sites throughout Great Bay and Little Egg Harbor. I used 3 fish per cage for the flounder and tautog experiments and 5 in the goby experiment. These levels did not exceed naturally occurring densities. Maximum densities per $\mathrm{m}^{2}$ from throw trap sampling in the same estuaries over a $3 \mathrm{yr}$ period (Sogard unpubl. data) were 5 for $P$. americanus, 7 for $T$. onitis, and 9 for $G$. bosci.

The cage design was slightly modified throughout 1988 in an attempt to improve recovery of experimental fishes. The final design, used in 1989, consisted of a $1 \mathrm{~m}^{2}$ wood frame with stiff plastic mesh $(3 \mathrm{~mm}$ in diameter) on the sides ( $46 \mathrm{~cm}$ high) and top, and galvanized steel edges $(5 \mathrm{~cm}$ deep) around the bottom. Cages used in 1988 were similar, but had flexible mesh netting (5 mm diameter) on the sides and top, and aluminum flashing around the bottom.

For an experiment, the cage was planted on the 
Table 1. Design of the growth experiments for winter flounder Pseudopleuronectes americanus, tautog Tautoga onitis, and naked goby Gobiosoma bosci. In 1988 there were 4 cages per site ( 2 in each habitat) and a total of 16 cages per experiment. In 1989 there were 6 cages per site (with 3 per habitat) and a total of 24 cages per experiment. All flounder and tautog experiments used 3 fish per cage; the goby experiment used 5 fish per cage. Size range and mean size are total lengths in mm at the beginning of each experiment

\begin{tabular}{|c|c|c|c|c|c|c|c|}
\hline Experiment & $\begin{array}{l}\text { Start } \\
\text { date }\end{array}$ & $\begin{array}{l}\text { Duration } \\
\text { (d) }\end{array}$ & $\begin{array}{l}\text { Size } \\
\text { range }\end{array}$ & $\begin{array}{l}\text { Mean } \\
\text { size }\end{array}$ & $\begin{array}{c}\text { No. of cages } \\
\text { with fish } \\
\text { recovered }\end{array}$ & $\begin{array}{l}\text { Number } \\
\text { of fish } \\
\text { recovered }\end{array}$ & $\%$ Recovery \\
\hline \multicolumn{8}{|l|}{1988} \\
\hline Flounder 1 & Jun 2 & 10 & $23-41$ & 29.4 & 7 & 11 & 23 \\
\hline Flounder 2 & Jun 20 & 10 & $29-65$ & 46.7 & 12 & 24 & 50 \\
\hline Flounder 3 & Jul 14 & 15 & $56-84$ & 71.4 & 9 & 22 & 46 \\
\hline Tautog 1 & Aug 2 & 7 & $31-66$ & 43.9 & 14 & 33 & 69 \\
\hline Tautog 2 & Aug 15 & 10 & $36-73$ & 51.3 & 11 & 31 & 65 \\
\hline Tautog 3 & Aug 30 & 10 & $35-81$ & 52.8 & 15 & 39 & 81 \\
\hline Tautog 4 & Sep 12 & 10 & $35-85$ & 56.8 & 15 & 38 & 79 \\
\hline \multicolumn{8}{|l|}{1989} \\
\hline Flounder 4 & May 22 & 10 & $22-41$ & 29.2 & 23 & 63 & 88 \\
\hline Flounder 5 & Jun 5 & 10 & $28-50$ & 37.0 & 24 & 64 & 89 \\
\hline Flounder 6 & Jun 19 & 10 & $37-71$ & 54.3 & 24 & 70 & 97 \\
\hline Goby 1 & Aug 16 & 15 & $18-38$ & 27.7 & 24 & 95 & 79 \\
\hline
\end{tabular}

desired substrate, with the metal edges embedded in the sediment. A $30 \mathrm{~cm}$ wide skirt of mesh netting around the bottom of the cage was staked out to the adjacent substrate, preventing toadfish Opsanus tau and crabs from burrowing down along the cage sides. The cages were cleared of resident fishes and decapods using a bar seine similar to that used with the throw traps. The removable lids were then bolted on and the experimental fishes, which had previously been measured, weighed, and individually marked with a small injection of acrylic paint, were added through an access port in the cage top. Fishes were randomly assigned to cages. Within each experiment there was no significant difference in initial fish size (total length) among sitehabitat treatments (2-way ANOVAs, all p > 0.05 for all experiments). At the end of an experiment the lid was removed and fish collected with the bar seine. They were immediately returned to the laboratory and measured and weighed while still alive.

In 1988 cages were removed from the field between experiments and placed in new positions for the next experiment. In 1989 the cages were treated as more permanent structures. They were planted in place $2 \mathrm{wk}$ before the first flounder experiment and remained in place for the 3 flounder experiments, with 4 cages needing replacement or movement to new locations. Cage tops were not present between experiments, allowing both large and small organisms to enter the cage. After the third flounder experiment, all of the cages were removed from the field. They were placed in new positions for the goby experiment. While in the field the cages were regularly cleared of fouling organisms with stiff brushes.
Experiments in 1988 employed 2 cages in vegetation (either Zostera or Ulva) and 2 cages on unvegetated sand/mud at each site (Table 1). In 1989 that effort was expanded to 6 cages per site, 3 in vegetation and 3 in sand.

For the 3 flounder experiments in 1988, cages designated for the Ulva treatment were placed directly over existing patches of UIva. For the first tautog experiment, I was unable to find any Ulva patches at the GB 2 site. I therefore placed the cages on patches of a red alga (Gracilaria tikvahiae) since it would still provide more physical structure than the bare sand substrate. In subsequent tautog experiments at both $\mathrm{GB}$ sites, the Ulva present in each cage was supplemented with additional sea lettuce. The supplemental Ulva was collected immediately prior to placement in a cage. The Ulva was gathered into a bucket, then added to a cage; smaller prey species present in the algal mats were presumably included with these additions. In all 1989 Ulva treatments, cages were placed on bare sand and equivalent amounts of Ulva $(\bar{x}=60 \mathrm{~g}$ dry weight $)$ added to each cage. This approach was necessary to ensure that a substantial amount of algae was present, since natural Ulva densities were low in 1989 at both GB sites (Sogard \& Able 1991)

Differences in growth among the 4 sites and 2 habitats (vegetated and unvegetated) were assessed with 2-way ANOVAs for each experiment, using the mean growth for each cage as the tested variable. In unbalanced andyses, where no fish were recovered from one or more cages (Table 1), the sums of squares were adjusted according to the method of Snedecor \& Cochran (1980). Stepwise multiple comparisons tests 
(Ryan's Q, as recommended by Day \& Quinn 1989) were subsequently used to determine where significant differences among sites occurred. Because foraging value at the different sites and habitats could vary temporally, and fish could show ontogenetic differences in their response to variability in foraging quality, separate ANOVAs were conducted for each experiment. Separate analyses also allowed assessment of the consistency in foraging quality of the different sites and habitats across several experiments.

Gut contents. The gut contents of a subsample of experimental fishes recovered from cages at the end of each growth experiment (including each site and habitat and the full size range) were removed and identified in general categories. These prey types were ranked in abundance for each fish and the mean rank and frequency of occurrence determined.

Prey availability. My primary goal with the prey analysis was to directly compare prey densities inside each cage with the growth rate of the enclosed fish (via regression analysis). In addition, I needed to ensure that the experimental fish were not severely depleting food resources within each cage during the course of an experiment, which would lead to non-representative growth rates compared to free-ranging fish. I estimated prey densities outside cages to assess natural variability among the different sites and habitats and across the summer. Finally, I compared prey densities inside the cage with those outside the cage to allow assessment of how well the substrates inside the cages matched natural densities.

Potential prey organisms were collected in conjunction with each growth experiment conducted in 1989 , using a $28 \mathrm{~mm}$ diameter corer. For densities outside the cages, 5 cores from vegetated substrates and 5 from unvegetated substrates at each site were collected at the beginning and end of each experiment (Flounder 4 , 5 and 6 and Goby 1). In Zostera the corer was randomly placed; for Ulva samples the algae was gently moved aside and the corer plunged into the underlying sediment. In addition, at the beginning and end of each experiment, 3 cores were collected inside each of the 24 cages. Because Ulva was not initially present in vegetated treatments at the GB sites in 1989, the beginning cores inside Ulva cages actually represented unvegetated substrate. The total number of core samples processed was 195 outside cages and 567 inside cages.

For each sample, the top $5 \mathrm{~cm}$ of sediment and the overlying water column in the corer were retained, preserved in $5 \%$ formalin, and stained with rose bengal. In the laboratory, core samples were decanted over a $163 \mu \mathrm{m}$ sieve and the retained animals counted under a dissecting scope. Additional decantings revealed only a few additional crustaceans; therefore only a single decanting and sieving process was used. The $163 \mu \mathrm{m}$ sieve retained adult copepods in the size range found in fishes' guts, but allowed copepodites and nauplii to pass. Few of the latter 2 groups were found in the fishes' guts. Organisms in the following prey groups were enumerated: copepods (nearly all were harpacticoids), amphipods, ostracods, polychaetes, and other crustaceans (including mysid shrimp and isopods).

To provide an estimate of additional organisms that might be present directly on macroalgae and eelgrass blades (and thus not included in sediment cores), in mid-summer I collected 5 samples of vegetation at each site, gently moving small amounts of either eelgrass or sea lettuce into plastic bags under water. In the laboratory this material was repeatedly rinsed over a $163 \mu \mathrm{m}$ sieve and the collected animals counted. Dry weight of the vegetation was determined and prey densities per g dry weight calculated.

To determine if growth rates of the experimental fishes were correlated with food availability, I conducted stepwise multiple regression analyses. Prey densities inside each cage at the beginning and end of an experiment, along with sediment silt/clay proportions, were available as independent variables, with the mean growth for each cage as the dependent variable. To determine if fish predation and/or prey emigration caused significant reductions in available prey, I conducted Wilcoxon paired comparisons of prey inside each cage at the beginning and end of each experiment. Variability in prey across sites, habitats, and sampling dates was analyzed with 3-way ANOVAs on core samples collected outside cages. The degree to which prey inside cages matched natural densities outside cages was addressed with paired Wilcoxon tests, with separate analyses for the beginning and end of each experiment.

\section{RESULTS}

\section{Site contrasts in environmental parameters}

The 4 sites differed in sediment composition, water temperatures and vegetation densities. Because of the ephemeral nature of the Ulva patches, sediment sizes were assumed to be similar within each GB site, regardless of the presence or absence of UIva. Sediment comparisons for the $2 \mathrm{~GB}$ sites and both habitats at the LEH sites revealed significantly different silt/clay fractions (Table 2; ANOVA, $F=41.5, \mathrm{p}<0.001$ ).

During the 3 flounder experiments in 1989, mean daily water temperatures were consistently warmer (by around $2^{\circ} \mathrm{C}$ ) at the $\mathrm{LEH}$ sites than at the $\mathrm{GB}$ sites (Table 3). In late summer, during the goby experiment, temperatures were more closely matched among the 4 sites, with no significant differences. Salinities ranged 
Table 2. Mean values of sediment silt/clay fractions (SD in parentheses) at the 4 sites used in throw trap sampling and growth experiments. LEH = Little Egg Harbor; GB = Great Bay. Sediment values are based on 3 samples each. Both habitats were sampled at LEH sites; sediments under Ulva patches at the GB sites were assumed to be similar in size structure to unvegetated habitats. Values with the same superscript were not significantly different, based on Ryan's $Q$ multiple comparisons

\begin{tabular}{|ccccccc|}
\hline \multicolumn{2}{c}{ LEH 1} & \multicolumn{2}{c}{ LEH 2 } & \multirow{2}{*}{ GB 1 } & GB 2 \\
Sand & Grass & Sand & Grass & & \\
\hline $4.7^{\mathrm{a}}$ & $16.6^{\mathrm{b}}$ & $5.5^{\mathrm{a}}$ & $9.8^{\mathrm{c}}$ & $16.5^{\mathrm{b}}$ & $4.9^{\mathrm{a}}$ \\
$(1.1)$ & $(1.8)$ & $(0.3)$ & $(0.5)$ & $(2.6)$ & $(1.4)$ \\
\hline
\end{tabular}

from 26 to $34 \mathrm{ppt}$ over the $2 \mathrm{yr}$ of the study, but were closely similar among sites within sampling periods.

To summarize site differences in vegetation (further described in Sogard \& Able 1991), Zostera shoot densities were not significantly different between the 2 LEH sites (ANOVA), but because eelgrass blades were longer and wider at the LEH 1 site, Zostera standing crops were significantly higher than at the LEH 2 site. At both sites there was a significant decline in shoot density and standing crop from 1988 to 1989. Ulva standing crops in vegetated patches at the $2 \mathrm{~GB}$ sites also declined significantly between 1988 and 1989 . Although Ulva densities at the GB 1 site were higher than at the GB 2 site in 1988, the very low densities at both sites in 1989 resulted in a non-significant site factor in ANOVA comparisons (Sogard \& Able 1991).

\section{Natural fish densities}

Pseudopleuronectes americanus were more abundant on unvegetated substrates (Fig. 2); this difference was statistically significant in 1989 but not 1988 (Table 4). They also varied in abundance across sites; this difference was significant in 1988, when they were more abundant at the GB sites, but not in 1989. A total of 8 winter flounder were collected from vegetated habitats, while 25 individuals were collected from unvegetated habitats. Tautoga onitis, in contrast, were never collected from sand or mud substrates during throw trap sampling, indicating a strong preference for vegetation (Fig. 2). In 1988, they were significantly more abundant in vegetation and at the GB sites (Table 4). A significant site-by-habitat interaction in the ANOVA resulted from their greater abundance in Ulva $(\mathrm{n}=17)$ than in Zostera $(\mathrm{n}=1)$ ). In 1989 no conclusions about habitat preference could be drawn due to the very low densities associated with an apparent recruitment failure in the study area (total caught in throw trapping $=3$ ). Gobiosoma bosci was more abundant
Table 3. Results of 1-way ANOVAs comparing the mean daily water temperature at each site during each of 4 growth experiments conducted in 1989. Sites are listed in order of increasing temperature with the mean presented below the site; underlined means were not significantly different (Ryan's $Q$ multiple comparisons test, $\alpha=0.05$ )

\begin{tabular}{|c|c|c|c|c|c|}
\hline Experiment & \multicolumn{4}{|c|}{ Mean temperature $\left({ }^{\circ} \mathrm{C}\right)$} & $F$ \\
\hline Flounder 4 & $\begin{array}{l}\text { GB2 } \\
18.5\end{array}$ & $\begin{array}{l}\text { GB1 } \\
18.6\end{array}$ & $\begin{array}{c}\text { LEH1 } \\
20.3\end{array}$ & $\begin{array}{c}\text { LEH2 } \\
20.5\end{array}$ & $5.98^{\circ}$ \\
\hline Flounder 5 & $\begin{array}{l}\text { GB1 } \\
20.7 \\
\end{array}$ & $\begin{array}{l}\text { GB2 } \\
20.9 \\
\end{array}$ & $\begin{array}{c}\text { LEH1 } \\
22.1 \\
\end{array}$ & $\begin{array}{c}\mathrm{LEH} 2 \\
22.6 \\
\end{array}$ & $9.75 \cdots$ \\
\hline Flounder 6 & $\begin{array}{l}\text { GB1 } \\
24.1 \\
\end{array}$ & $\begin{array}{l}\text { GB2 } \\
24.3 \\
\end{array}$ & $\begin{array}{c}\text { LEH } 1 \\
26.4 \\
\end{array}$ & $\begin{array}{c}\mathrm{LEH} 2 \\
26.5 \\
\end{array}$ & $28.3^{\cdots} \cdot$ \\
\hline Goby 1 & $\begin{array}{l}\text { GB1 } \\
24.5\end{array}$ & $\begin{array}{l}\text { GB2 } \\
24.8\end{array}$ & $\begin{array}{c}\text { LEH1 } \\
24.8\end{array}$ & $\begin{array}{c}\mathrm{LEH} 2 \\
24.9\end{array}$ & 1.77 \\
\hline
\end{tabular}

than the other 2 species overall, with 200 collected from vegetated habitats and 47 from unvegetated habitats during throw trap sampling. They occurred in all sites and habitats (Fig. 2), but were significantly more abundant in vegetation in both years (Table 4). Their higher density at the LEH sites was significant in 1989 but not 1988. The interaction term in both years was significant, presumably due to differences in the degree of contrast between vegetated and unvegetated substrates at the 4 sites (Fig. 2).

\section{Growth experiments}

\section{Pseudopleuronectes americanus}

Problems with my initial method of cage placement caused a poor recovery rate of fish from the first flounder experiment in 1988 (Table 1); the results are reported here simply to demonstrate the amount of growth, allowing comparison with 1989 experiments. Recovery improved in Experiments 2 and 3, and in 1989, with the new cage design and increased replication, recovery averaged $91 \%$. To determine if growth was related to the density of fish in a cage, I conducted a paired comparisons $t$-test, with pairs consisting of mean growth rates in cages with the same experimental treatment (site and habitat) but different numbers of fish recovered. Growth was higher in cages with the greater number of fish recovered $(t=3.18, \mathrm{p}<0.01, \mathrm{n}=$ 14 pairs). However, the average difference between cages with different recovery rates was only $0.10 \mathrm{~mm}$ $\mathrm{d}^{-1}$ for 1 vs 2 fish recovered, $0.11 \mathrm{~mm} \mathrm{~d}^{-1}$ for 1 vs 3 fish recovered, and $0.09 \mathrm{~mm} \mathrm{~d}^{-1}$ for 2 vs 3 fish recovered. Moreover, mean growth rates between cages with different recovery rates (within treatments) were no 
Fig. 2. Pseudopleuronectes americanus, Tautoga onitis, and Gobiosoma bosci. Mean densities per $\mathrm{m}^{2}(+\mathrm{SE})$ of fish collected in throw trap sampling in 1988 and 1989 in vegetated and unvegetated habitats at 4 sites. Sampling was conducted every $2 \mathrm{wk}$ from May through September each year. Site codes: LEH1, Little Egg Harbor 1; LEH2, Little Egg Harbor 2; GB1, Great Bay 1; GB2, Great Bay 2
1988
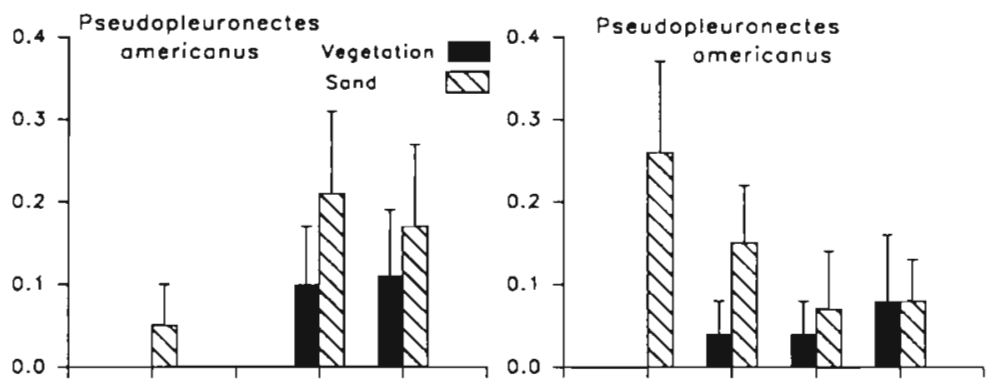

N
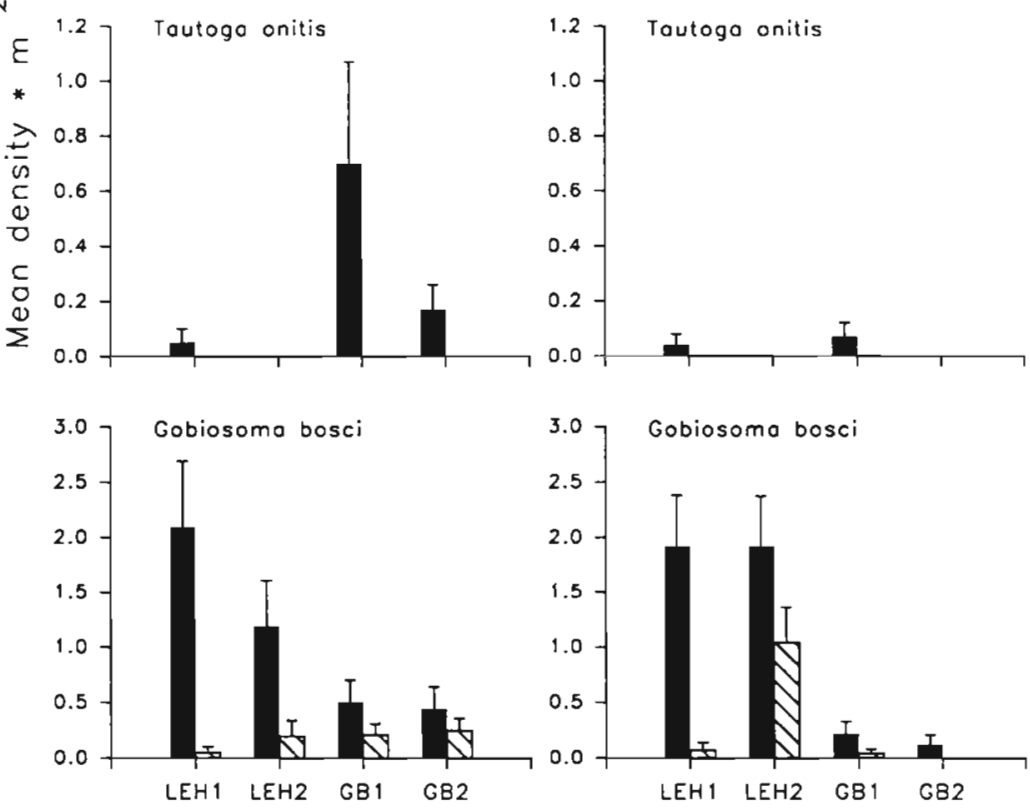

more variable (mean $\mathrm{SD}=0.83$ ) than growth rates between cages with equal numbers of fish recovered (mean $\mathrm{SD}=0.93$ ). Because growth differences due to different recovery rates were small relative to differences among site-habitat treatments, I concluded that flounder density had a minimal influence on growth inside a cage. Thus, all of the cages were included in subsequent analyses.

For individual flounder, the increase in total length during caging experiments varied from -1.5 to +13.3 $\mathrm{mm}$, and growth in weight ranged from -1.3 to $+1.6 \mathrm{~g}$, demonstrating a broad range over a very short period of time. For a few fast-growing small flounder, body weight was quadrupled over a $10 \mathrm{~d}$ period. Differences in growth depended on habitat and site in the estuary; these differences were consistent across the 2 yr of the study (Fig. 3). Trends in growth in weight generally matched those of growth in length (Sogard 1990); results discussed here will focus on growth in length.

Results of 2-way ANOVAs using site and habitat (vegetated or unvegetated) as factors demonstrated significant site differences in growth for 4 of the 5 experiments tested (Table 5; Experiment 1 was not analyzed due to the low recovery rate). Habitat was significant (growth better in sand than vegetation) only in Experiment 4. Site comparisons (Table 6) showed that the poorest growth was always at an LEH site (usually LEH 2) and the best growth was always at a GB site (usually GB 2). The site-by-habitat interaction was always non-significant (Table 5), suggesting that the contrast between vegetated and unvegetated habitats was not dependent on the site or vegetation type (i.e. Ulva vs Zostera).

To determine how closely growth rates inside the cages matched those of uncaged flounders, I compared growth during experiments with the progression of standard lengths of fishes caught in throw trap sampling. Due to the small number of flounder collected at the 4 experimental sites, I included length data from 64 flounder collected at an additional site in Great Bay that was used in artificial seagrass experiments (Sogard 1990). Only 1989 data were included due to the low total number of winter flounder collected in 1988. Although the size progression of wild-caught fishes 
Table 4. Pseudopleuronectes americanus, Tautoga onitis, and Gobiosoma bosci. Results of 2-way ANOVAs comparing the density (no. $\mathrm{m}^{-2}$ ) of juvenile flounder, tautog and gobies among sites and habitat (vegetated vs unvegetated) for 1988 and 1989 (not enough tautog were collected in 1989 to allow analysis). $F$ values for factors of site, habitat, and their interaction are reported, and the level of significance indicated. All values were $\log$-transformed ( $\log x+1)$ prior to analysis, and all sampling periods with no fish caught of the species being tested were excluded from analysis $\mathrm{n}=$ no. of throw trap samples included in the analysis

\begin{tabular}{|c|c|c|c|}
\hline & Site & $\begin{array}{l}\text { Fvalue } \\
\text { Habitat }\end{array}$ & $\begin{array}{l}\text { Site } \times \\
\text { Habitat }\end{array}$ \\
\hline \multicolumn{4}{|l|}{1988} \\
\hline $\begin{array}{l}P . \text { americanus } \\
(\mathrm{n}=123)\end{array}$ & $2.76^{\circ}$ & 1.00 & 0.15 \\
\hline $\begin{array}{l}T \text {. onitis } \\
\quad(\mathrm{n}=62)\end{array}$ & $5.03^{\cdots}$ & $14.72 \cdots$ & $5.04 \cdots$ \\
\hline $\begin{array}{l}\text { G. bosci } \\
\quad(\mathrm{n}=94)\end{array}$ & 1.21 & $39.59 \cdots$ & $4.46^{\circ}$ \\
\hline \multicolumn{4}{|l|}{1989} \\
\hline $\begin{array}{c}\text { P. americanus } \\
(\mathrm{n}=141)\end{array}$ & 0.50 & $5.49^{\circ}$ & 1.53 \\
\hline $\begin{array}{l}\text { G. bosci } \\
\quad(\mathrm{n}=143)\end{array}$ & $27.58 \cdots$ & $32.49 \cdots$ & $8.55^{\cdots} \cdot$ \\
\hline \multicolumn{4}{|c|}{$\cdot p<0.05, \cdots p<0.01, \cdots p<0.001$} \\
\hline
\end{tabular}

provides only a rough estimate of natural growth rates, growth inside the cages appeared to be similar to that outside the cages (Fig. 4).

\section{Tautoga onitis}

Recovery rates for the 4 tautog experiments in 1988 ranged from 65 to $81 \%$ (Table 1). The mean growth rate in a cage was not significantly influenced by the number of fish recovered (paired comparisons $t$-test, $t=0.28, \mathrm{n}=9$ ). The average difference for cages with different recovery rates within a site-habitat treatment was $0.107 \mathrm{~mm} \mathrm{~d}^{-1}$

For individual tautog, growth during an experiment varied from -1.3 to $+8.0 \mathrm{~mm}$ in length and -1.14 to $+1.73 \mathrm{~g}$ in weight. In contrast to Pseudopleuronectes americanus, growth for Tautoga onitis at all 4 sites was usually greater in vegetation than on unvegetated substrates (Fig. 5). In 2-way ANOVAs this habitat difference was significant in Experiments 2 and 4 (Table 5). Significant differences among the 4 sites occurred in Experiments 1 and 3 . The site-by-habitat interaction was significant only in Experiment 4, again suggesting that the site and type of vegetation present did not affect the contrast in growth between vegetated and unvegetated substrates. In site comparisons, tautog growth was always best at the GB 1 site (Table 6).

Growth rates in the cages were compared with the mean standard lengths of fishes collected from throw trapping in 1988, supplemented with 221 additional tautog collected from artificial seagrass at another Great Bay site (Sogard 1990). Growth inside the cages was initially comparable to natural rates, but dropped below natural rates over the 4 experiments (Fig. 4).

\section{Gobiosoma bosci}

For the goby experiment, $79 \%$ of the caged fish were recovered. Growth rates were again not related to the number of fish recovered from cages (paired comparisons $t$-test, $t=0.82, \mathrm{n}=8$ ). On average, growth rates differed by only $0.05 \mathrm{~mm} \mathrm{~d}^{-1}$ between cages with different recovery rates.

Individual Gobiosoma bosci demonstrated substantial variability in growth, with total length increases of 0.6 to $11.1 \mathrm{~mm}$ and weight increases of 0.03 to $0.76 \mathrm{~g}$ during the $15 \mathrm{~d}$ experiment. Some fish tripled their weight during this period. Eelgrass supported the slowest growth, with higher rates in sand at the LEH sites, whereas at the GB sites growth was slightly better in Ulva than in sand (Fig. 6). Results from ANOVA demonstrated a significant difference among sites but not between habitats (Table 5). Although for this species there did appear to be an influence of vegetation type on the contrast between vegetation and sand (Fig. 6), the site-by-habitat interaction was not significant. Multiple comparisons tests indicated significantly higher growth in Great Bay than in Little Egg Harbor (Table 6).

Growth rates of Gobiosoma bosci inside cages appeared to be slightly higher than outside the cages, based on the progression of standard lengths from fishes collected in 1989 throw trap sampling at the 4 sites (Fig. 4).

\section{Gut contents}

Experimental fishes of all 3 species consumed primarily amphipods and harpacticoid copepods while in the cages (Table 7). Other prey groups were relatively rare in the diets. There were no obvious differences in diet among the sites and habitats used in caging experiments.

\section{Prey densities}

Natural prey densities, based on core samples collected from outside of cages, varied among sites and 
Fig. 3. Pseudopleuronectes americanus Mean increase in total length $(+\mathrm{SE})$ for juveniles during each caging experiment in vegetated and unvegetated substrates at 4 sites in New Jersey estuaries. Site codes as in Fig. 2. Vegetation is eelgrass Zostera marina at LEH sites and sea lettuce Ulva lactuca at GB sites. Asterisks denote treatments where no experimental fishes were recovered

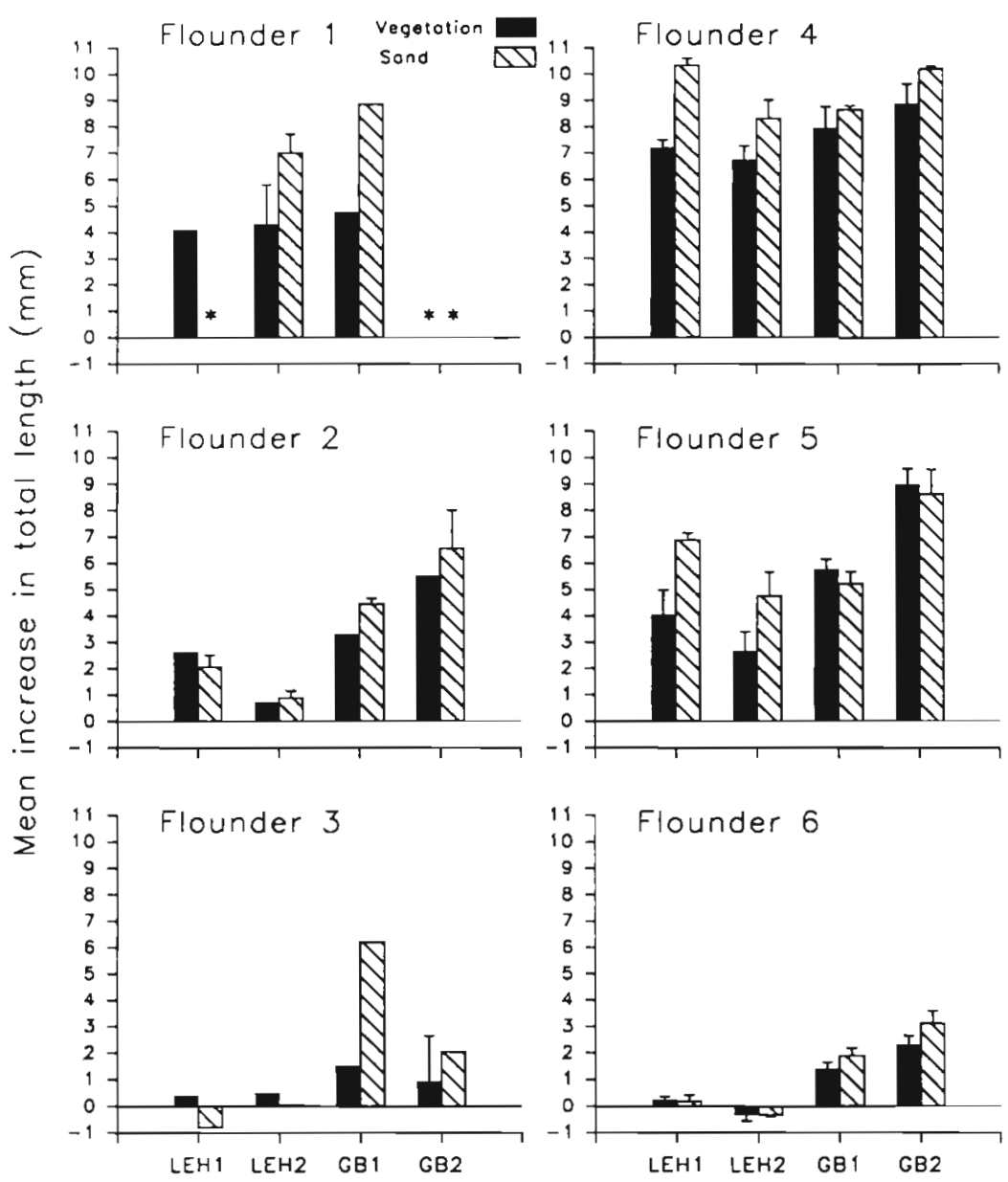

Table 5. Pseudopleuronectes americanus, Tautoga onitis, and Gobiosoma bosci. Results of 2-way ANOVAs comparing the increase in total length $(\mathrm{mm})$ among sites and habitat (vegetated vs unvegetated) for each growth experiment (not enough fish were recovered from the first flounder experiment to allow analysis). $F$ values and their significance levels are reported for factors of site, habitat, and their interaction

\begin{tabular}{|c|c|c|c|}
\hline \multirow[t]{2}{*}{ Experiment } & \multicolumn{3}{|c|}{$F$ value } \\
\hline & Site & Habitat & $\begin{array}{c}\text { Site } \times \\
\text { Habitat }\end{array}$ \\
\hline Flounder 2 & $13.3^{\circ}$ & 0.4 & 0.4 \\
\hline Flounder 3 & 1.1 & 0.4 & 0.6 \\
\hline Flounder 4 & $5.3^{\circ}$ & $17.4^{\circ}$ & 1.7 \\
\hline Flounder 5 & $18.9^{\cdots}$ & 4.1 & 3.1 \\
\hline Flounder 6 & $49.1^{\cdots} \cdots$ & 2.6 & 1.1 \\
\hline Tautog 1 & $5.2^{\circ}$ & 2.3 & 0.0 \\
\hline Tautog 2 & 3.6 & $17.4^{\circ}$ & 1.7 \\
\hline Tautog 3 & $14.3^{\cdots}$ & 3.7 & 1.3 \\
\hline Tautog 4 & 3.0 & $78.3^{\cdots}$ & $18.6^{* *}$ \\
\hline Goby 1 & $32.3 \cdots$ & 0.8 & 1.8 \\
\hline$\cdot \mathrm{p}<0.05$ & $01 ; \cdots$ & 0.001 & \\
\hline
\end{tabular}

between vegetated and unvegetated habitats (Figs. 7 to 9). Three-way ANOVAs revealed significant site differences for all 4 taxa (Table 8). Amphipods and copepods, the major diet items, were most abundant at the GB 1 site. Habitat was a significant factor only for copepods and polychaetes, with both more abundant in unvegetated substrates. Definitive temporal patterns in abundance could not be recognized. Densities were significantly different across sampling dates only for amphipods (Table 8), which increased at the end of June, then declined during the goby experiment (Fig. 8).

Meiofauna collected directly from eelgrass blades and Ulva fronds indicated that the vegetation supplied additional potential prey over that of the sediment (as estimated from core samples). On a bottom area basis, vegetation increased the number of copepods by an average of $49 \%(\mathrm{LEH} \mathrm{1)}$ and $7 \%(\mathrm{LEH} \mathrm{2})$ in Zostera habitats and by $12 \%$ (GB 1) and $15 \%$ (GB 2) in Ulva habitats. Amphipod densities were enhanced on average by $64 \%$ (LEH 1 ) and $22 \%$ (LEH 2) in Zostera, and 
Table 6. Pseudopleuronectes americanus, Tautoga onitis, and Gobiosoma bosci. Results of Ryan's $Q$ multiple comparisons tests indicating significant differences in growth in total length $(\mathrm{mm})$ among 4 sites. Sites are presented in order of increasing growth, with the mean increase in total length for each experiment listed under each site; underlined means were not significantly different at the $\alpha=0.05$ level. $F$ values from the 2-way ANOVAs are reported in Table 4

\begin{tabular}{|lcccc|}
\hline Experiment & \multicolumn{2}{c}{ Sites in order of increasing growth } \\
\hline Flounder 2 & LEH 2 & LEH 1 & GB 1 & GB 2 \\
& 0.83 & 2.25 & 4.06 & 6.21 \\
Flounder 3 & LEH 1 & LEH 2 & GB 2 & GB 1 \\
& -0.20 & 0.27 & 1.29 & 3.85 \\
Flounder 4 & LEH 2 & GB 1 & LEH 1 & GB 2 \\
& 7.52 & 8.30 & 9.07 & 9.53 \\
Flounder 5 & LEH 2 & LEH 1 & GB 1 & GB 2 \\
Flounder 6 & 3.71 & 5.46 & S.50 & 8.81 \\
Tautog 1 & LEH 2 & LEH 1 & GB 1 & GB 2 \\
& -0.33 & 0.21 & 1.64 & 2.70 \\
Tautog 2 & LEH 2 & GB 2 & LEH 1 & GB 1 \\
& 1.36 & 2.31 & 2.68 & 4.14 \\
Tautog 3 & GB 2 & LEH 2 & LEH 1 & GB 1 \\
& 1.95 & 2.22 & 2.43 & 3.40 \\
Tautog 4 & LEH 1 & LEH 2 & GB 2 & GB 1 \\
& LEH 1 & GB 2 & LEH 2 & GB 1 \\
Goby 1 & 0.24 & 0.51 & 0.66 & 0.86 \\
\hline & LEH 2 & LEH 1 & GB 1 & GB 2 \\
& 3.93 & 5.70 & 8.03 & 8.20 \\
\hline
\end{tabular}

$18 \%$ (GB 1) and $99 \%$ (GB 2) in Ulva. Because this analysis was conducted only in mid-summer, I was not able to assess potential temporal variation in prey densities on vegetation.

Cages (without tops) were placed in the field about $2 \mathrm{wk}$ before the start of the first experiment in 1989 (Flounder 4) and left in place for the 3 flounder experiments. The interval between Flounder 4 and 5 and between Flounder 5 and 6 was 4 d. To determine if prey densities inside cages adequately represented natural densities or were altered due to the presence of the cage, I compared cores collected inside to those from outside the cages at the beginning of each experiment. Copepod densities were higher inside cages in Flounder 4, copepod and ostracod densities were lower inside cages in Flounder 5, and there were no significant trends in Flounder 6 (Table 9). Thus, the cages did appear to influence initial prey densities, but this effect was not consistent in degree or direction across the 3 experiments tested

I conducted a similar analysis for core samples collected at the end of experiments, to determine if the combined effects of fish predation and cage effects
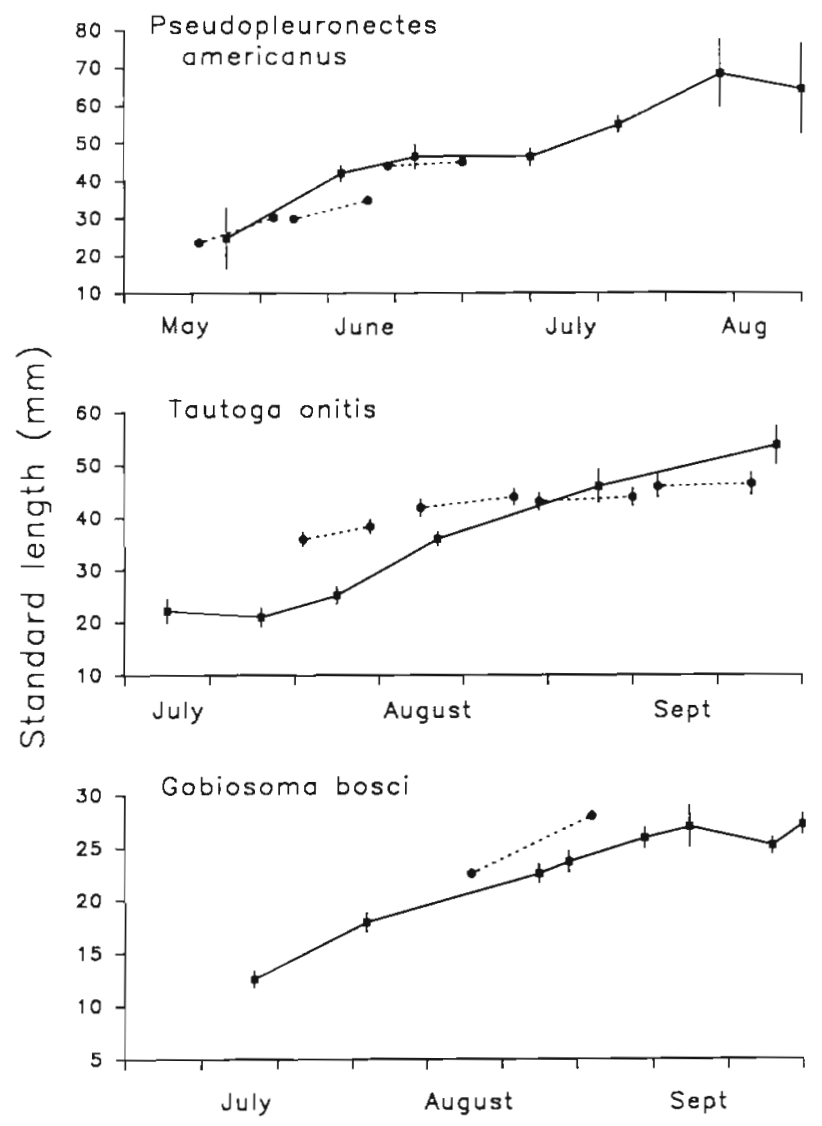

Fig. 4. Pseudopleuronectes americanus, Tautoga onitis, and Gobiosoma bosci. Seasonal progression in mean standard lengths (and SE) of fishes collected during throw trap sampling ( $)$ in shallow water habitats in Little Egg Harbor and Great Bay estuaries, New Jersey. Throw trap samples used for this study were supplemented with fishes collected from another study to increase the sample size. The mean initial and final size of fishes used in caging experiments $(\bullet)$ are depicted for comparison. P. americanus and $G$. bosci data are from 1989; $T$. onitis data are from 1988

significantly altered prey densities relative to natural levels. Copepod densities were significantly lower inside cages at the end of the Flounder 4,5 and 6 experiments. Densities of ostracods in Flounder 4 and amphipods and polychaetes in Flounder 6 were also lower inside cages (Table 9). There were no significant differences in inside vs outside densities at the end of the goby experiment.

Comparisons of the beginning and final prey densities within each cage (Wilcoxon paired tests) suggested that fish predation and/or prey emigration caused significant declines in copepods, amphipods, and ostracods in Flounder 4 (Table 10). In Flounder 6 , copepods decreased, but amphipods increased, indicating net immigration into the cages. In contrast, no changes in prey availability were observed over the course of the goby experiment and Flounder 5. 
Fig. 5. Tautoga onitis. Mean increase in total length $(+\mathrm{SE})$ for juveniles during each caging experiment in vegetated and unvegetated substrates at 4 sites in New Jersey estuaries. Site codes as in Fig. 2. Vegetation is eelgrass Zostera marina at LEH sites and sea lettuce UIva lactuca at GB sites. Asterisk denotes treatment where no experimental fishes were recovered
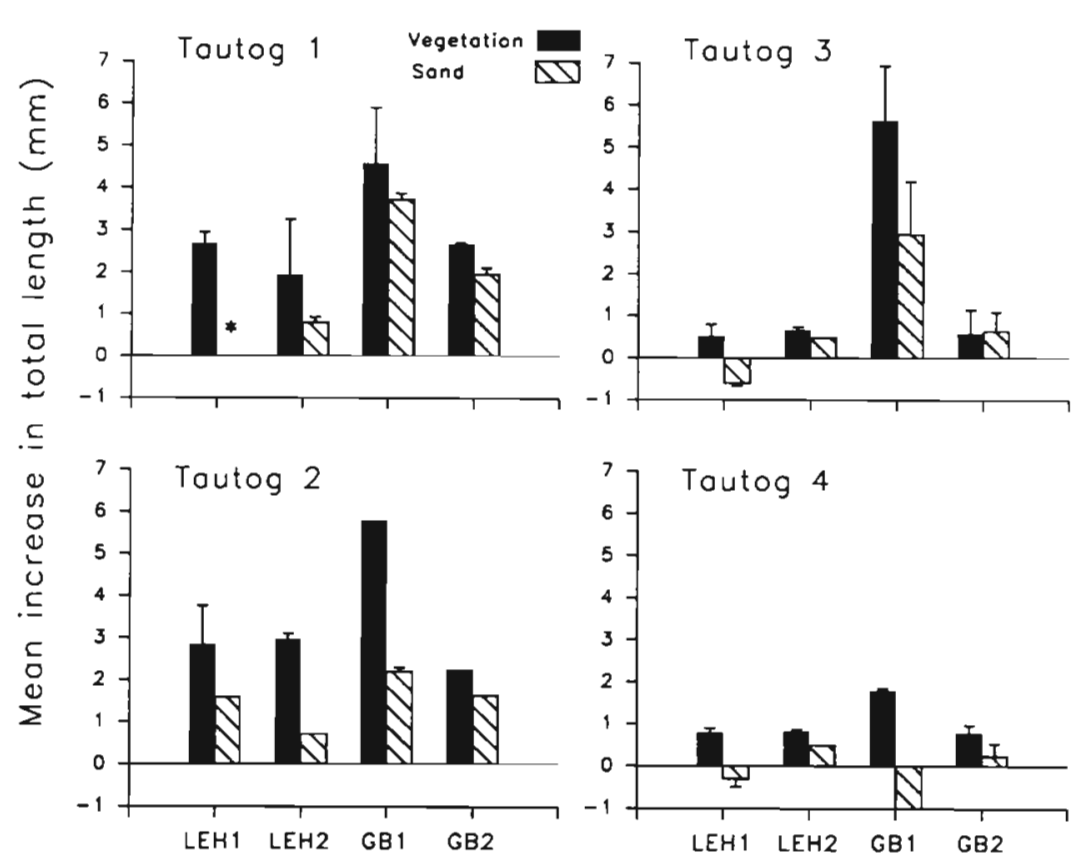

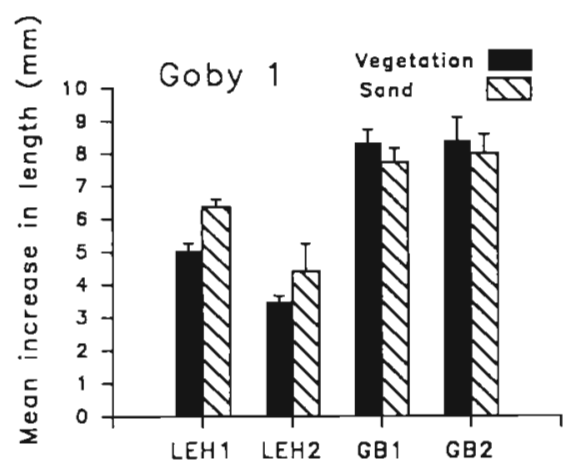

Fig. 6. Gobiosoma bosci. Mean increase in total length (+ SE) for juveniles during one caging experiment in vegetated and unvegetated substrates at 4 sites in New Jersey estuaries. Site codes as in Fig. 2. Vegetation is eelgrass Zostera marina at LEH sites and sea lettuce Ulva lactuca at GB sites

\section{Influence of sediment structure and prey density on growth}

The mean growth of fish in a cage was compared to sediment parameters and initial and final prey densities inside that cage with multiple regression analysis. For Flounder 4, growth was negatively related to the percentage of silt in the sediment; fish grew better in areas with coarser sediments (Table 11). Prey densities did not enter into regression equations, indicating no linear dependence of growth on food abundance. In Flounder 5 percentage silt again had a significant negative relationship with growth. In addition, growth was related to initial copepod densities, but negatively, with faster growth in cages with lower copepod densities. In Flounder 6, growth was significantly related to initial amphipod densities, but again

Table 7. Frequency of occurrence (Freq.) and mean rank in abundance of major prey groups consumed by Pseudopleuronectes americanus (no examined $=127)$, Tautoga onitis $(\mathrm{n}=63)$, and Gobiosoma bosci $(\mathrm{n}=32)$ during caging experiments. Gut contents were examined for a series of fish recovered from cages at each site and in each habitat for each experiment

\begin{tabular}{|c|c|c|c|c|c|c|}
\hline \multirow[t]{2}{*}{ Prey group } & \multicolumn{2}{|c|}{ P. americanus } & \multicolumn{2}{|c|}{$T$ onitis } & \multicolumn{2}{|c|}{ G. bosci } \\
\hline & Freq. & Rank & Freq. & Rank & Freq. & Rank \\
\hline Amphipods & 88.0 & 1.2 & 74.6 & 1.4 & 96.9 & 1.0 \\
\hline Copepods & 57.0 & 1.8 & 77.8 & 1.5 & 9.4 & 1.7 \\
\hline Ostracods & 16.5 & 2.0 & 14.3 & 1.9 & 0 & - \\
\hline Other crustaceans & 10.2 & 2.8 & 39.7 & 2.2 & 18.7 & 2.2 \\
\hline Polychaetes & 5.5 & 1.6 & 4.8 & 2.7 & 0 & - \\
\hline Mollusks & 3.9 & 3.1 & 4.8 & 2.7 & 0 & - \\
\hline
\end{tabular}




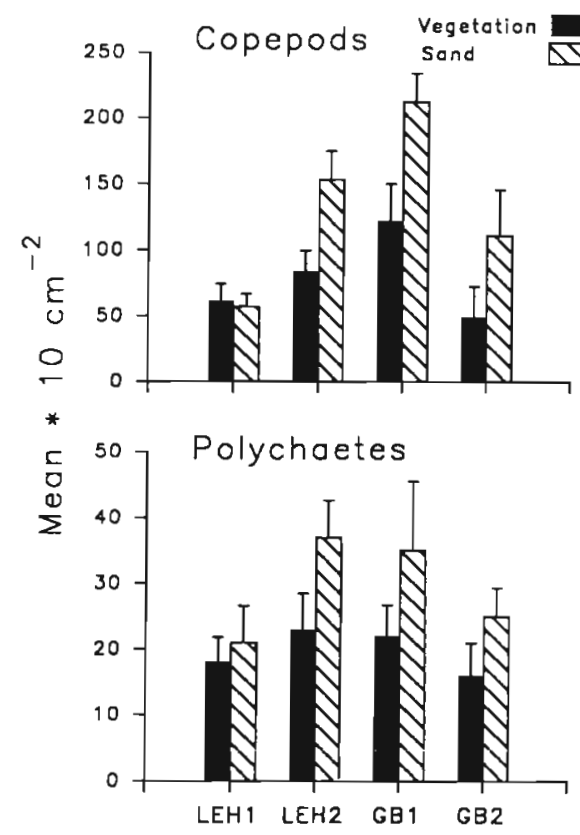

the relationship was negative. Silt did not enter into the equations.

The goby experiment did support the hypothesis of enhanced growth with enhanced prey availability. Growth was positively related to the initial density of amphipods and negatively related to the final density of copepods (Table 11). The latter relationship suggested substantial declines in copepod density in cages with more rapid fish growth; this response was particularly evident at the GB 1 site (Fig. 9).

\section{DISCUSSION}

\section{Caging method}

The caging procedure was effective in assessing relative contrasts in growth associated with physical location in the estuary and substrate type. Marked differences in absolute growth were detectable even over the short time period covered by the experiments. Growth rates inside the cages were comparable to those under natural conditions (Fig. 4). Growth rates estimated from otolith increment widths in winter flounder (Sogard \& Able in press) and increment counts in tautog (Sogard et al. in press) were also similar to those measured directly in caging experiments. Thus, confinement inside a cage did not appear to alter the growth potential of an individual fish.

Although the similarity in average growth of caged and uncaged fishes was encouraging, I could not rule out the potential influence of cage effects on prey availability. My primary concerns were that prey densities inside the cages were comparable to those outside, and that fish predation did not severely
Fig. 7. Mean densities (+ SE) of potential prey collected from core samples taken outside cages throughout summer 1989. Densities reported are means per $10 \mathrm{~cm}^{2}$ from vegetated and unvegetated substrates at 4 sites in New Jersey estuaries. Site codes as in Fig. 2. Vegetation is eelgrass Zostera marina at LEH sites and sea lettuce Ulva lactuca at $\mathrm{GB}$ sites deplete prey inside a cage during the course of an experiment. The prior presence of the cages in the field appeared to have some influence on initial prey densities, but this effect was inconsistent (Table 9). Likewise, the effect of fishes inside the cages on prey abundances varied, but suggested potential depletion of prey in the Flounder 4 experiment (Table 10). Significant differences between inside and outside densities at the end of experiments (Table 9) also suggested that immigration to the cages did not always match losses due to predation and emigration. Distinct patterns in the influence of the cages and the experimental fishes on prey may have been masked by the other processes causing the high spatial and temporal variability in densities (Figs. 8 \& 9).

In general, the caging method would appear to be a valuable tool for measuring field growth of small, relatively sedentary fishes during a phase of rapid growth. Limiting the duration of time spent in cages would minimize potential cage effects on prey availability.

\section{Density estimates}

I used throw traps to estimate natural fish densities because they allowed discrete sampling in a specific habitat and provided quantitative samples. Kushlan (1981) and Pihl \& Rosenberg (1982) noted capture efficiencies of 70 to almost $100 \%$ for similar traps in both vegetated and unvegetated substrates. Typical of this method, however, the throw trap sampling resulted in relatively small total catches. The validity of my density estimates was in part supported by their similarity to relative densities recorded by Able et al. (1989) using a 
Inside cores
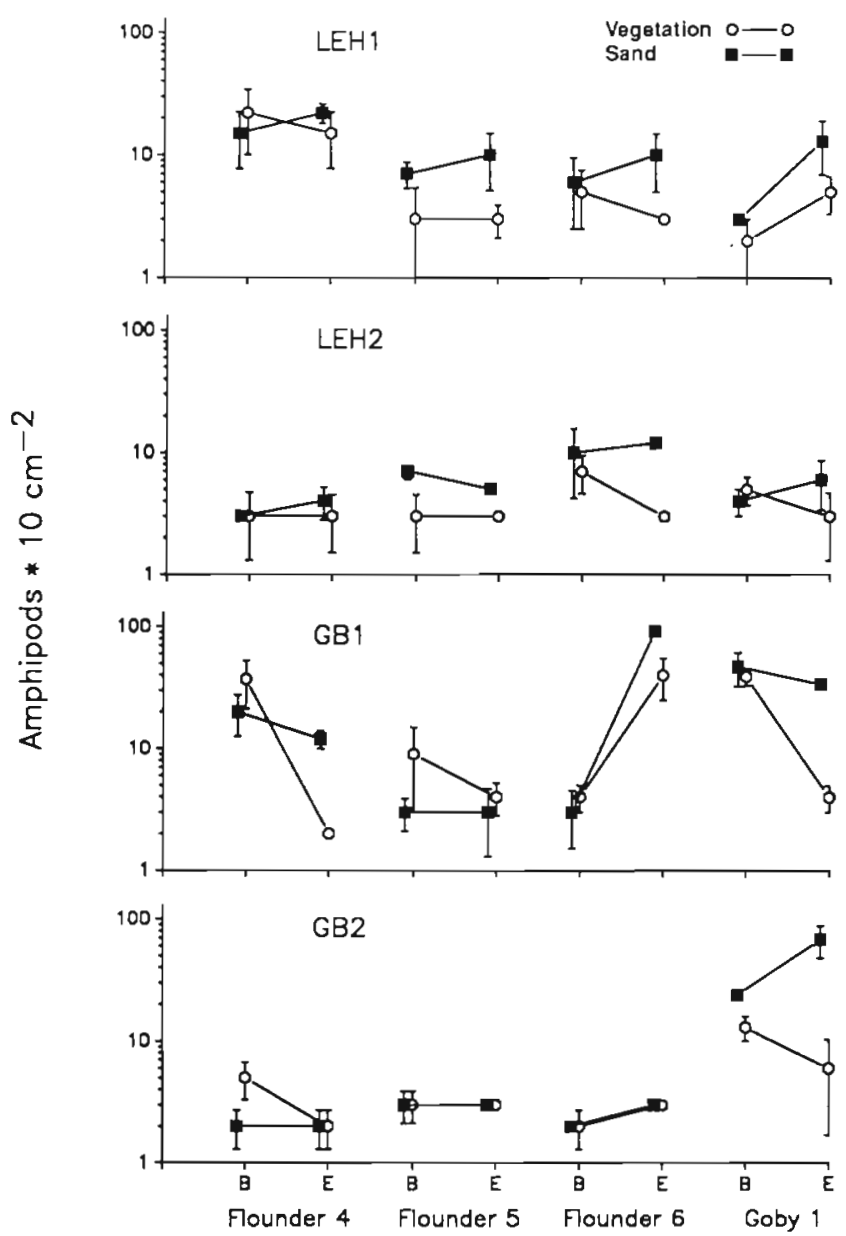

Outside cores
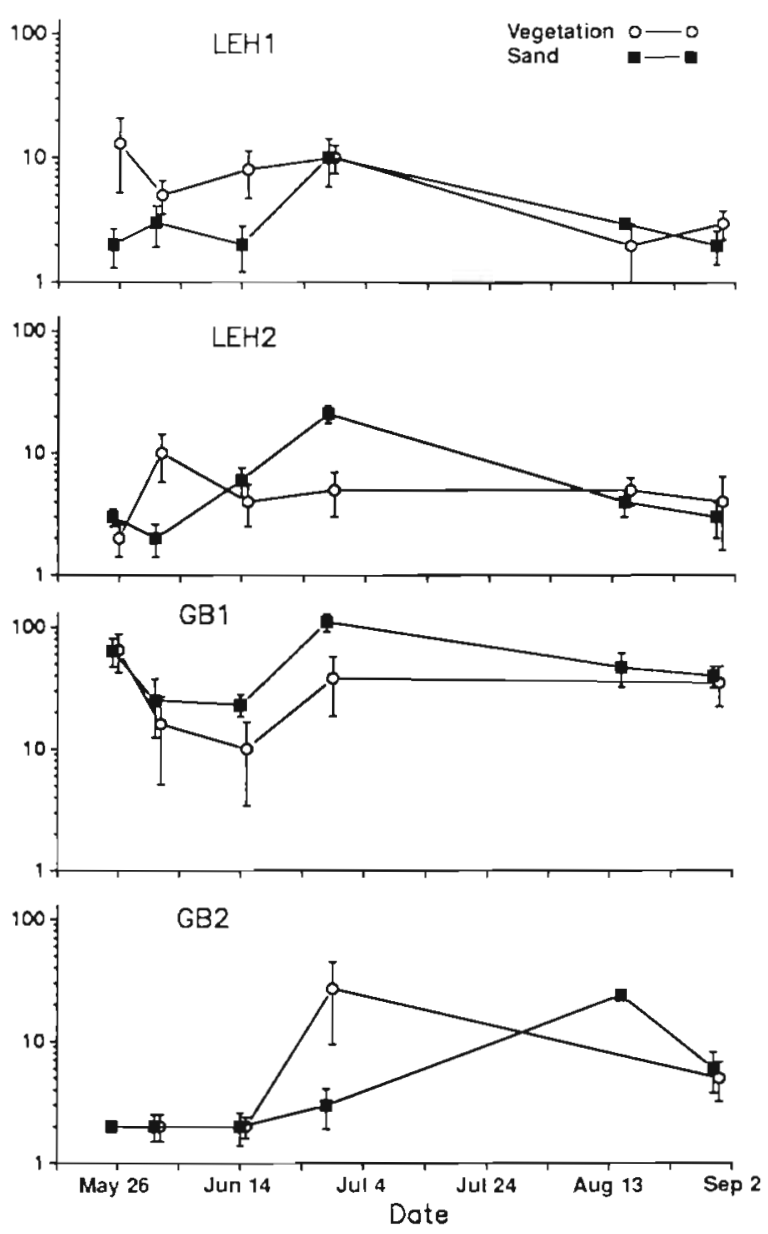

Fig. 8. Mean densities ( + SE) of amphipods per $10 \mathrm{~cm}^{2}$ in vegetated and unvegetated sediments at each site during summer 1989 . 'Inside cores' were collected inside cages at the beginning $(B)$ and end ( $E$ ) of each caging experiment (flounder experiments 4, 5, and 6 and the goby experiment). Vegetated treatments at the Great Bay sites involved addition of Ulva to cages; thus the beginning densities were actually from unvegetated substrates. 'Outside cores' were collected outside cages in conjunction with each growth experiment, and represent natural densities unaffected by the presence of cages. Note log scale for all graphs

different quantitative technique (suction sampling). Winter flounder in their study were also more abundant in unvegetated substrates, and, in vegetation comparisons, more abundant in Ulva than Zostera. As in this study, Able et al. (1989) collected tautog only in vegetated habitats, with more present in Ulva than Zostera. Naked gobies, likewise, were more abundant on vegetated than unvegetated substrates. In contrast to this study, Able et al. (1989) found higher goby densities in Ulva than Zostera; however, their macroalgal densities were substantially higher than in this study.

\section{Growth variability}

The caging experiments demonstrated high variability in growth rates under different environmental con- ditions for juvenile Pseudopleuronectes americanus, Tautoga onitis, and Gobiosoma bosci. Assuming that the probability of survival during the nursery period is an increasing function of fish size, this plasticity in growth rate implies that the site and habitat into which post-larvae settle from the plankton can indeed have a marked influence on population level dynamics.

The similarity of results across experiments indicated a consistency in relative foraging quality for both winter flounder and tautog. In 4 out of 5 flounder experiments, the poorest growth was at the LEH 2 site and the fastest growth was at the GB 2 site (Table 6). In all 4 of the tautog experiments the fastest growth was at the GB 1 site. Growth response was also similar across the 3 species used in this study; in all experiments the fastest growth occurred at a GB site, and in all but one experiment the slowest growth was at an LEH site. 

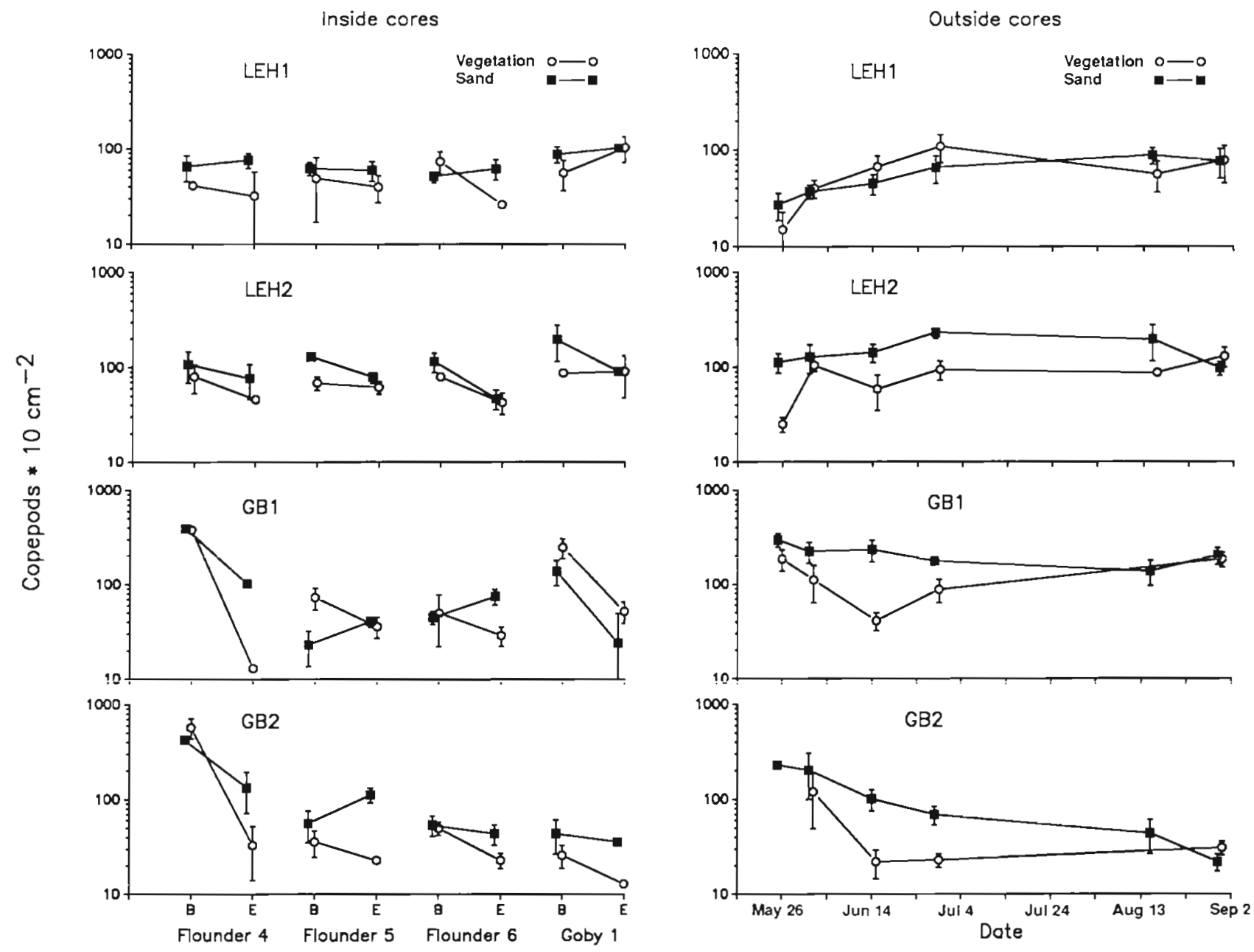

Fig. 9. Mean densities (+ SE) of copepods per $10 \mathrm{~cm}^{2}$ in vegetated and unvegetated sediments at each site during summer 1989. 'Inside cores' were collected inside cages at the beginning (B) and end (E) of each caging experiment (flounder experiments 4,5, and 6 and the goby experiment). Vegetated treatments at the Great Bay sites involved addition of Ulva to cages; thus the beginning densities were actually from unvegetated substrates. 'Outside cores' were collected outside cages in conjunction with each growth experiment, and represent natural densities unaffected by the presence of cages. Note log scale for all graphs

Table 8. Results of 3-way ANOVAs comparing mean densities of prey by collection date, site, and habitat (vegetated vs unvegetated). Densities used in analyses were the mean of 5 core samples collected outside cages for each site-habitat treatment; the MS of the 3-way interaction was used as the divisor for $F$ tests. All values were log-transformed prior to analysis

\begin{tabular}{|c|c|c|c|c|}
\hline Source of variation & Copepods & Amphipods & Polychaetes & Ostracods \\
\hline Date & 1.1 & $4.6^{\circ}$ & 2.7 & 3.1 \\
\hline Site & $16.8 \cdots$ & $28.3^{\cdots}$ & $5.2^{\bullet}$ & $12.6^{\cdots} \cdots$ \\
\hline Habitat & $16.5^{\cdots}$ & 1.2 & $10.2 \cdots$ & 1.1 \\
\hline Date $\times$ Site & $5.9^{\cdots}$ & 1.3 & $3.9^{\circ}$ & $4.2^{\circ}$ \\
\hline Date $\times$ Habitat & 2.3 & 0.6 & 3.0 & 0.8 \\
\hline Site $\times$ Habitat & 2.5 & 2.1 & 0.8 & 0.3 \\
\hline
\end{tabular}


Table 9. Results of Wilcoxon paired tests comparing densities of prey inside and outside of cages, listing the location of higher density and the significance level. Separate analyses were conducted for the beginning and end of each experiment. Values compared were the means of the 3 cores from each cage vs the mean of 5 replicate cores collected outside cages for the same sitehabitat treatment. The beginning of the goby experiment could not be tested because cages were not placed in the field until the actual initiation of the experiment

\begin{tabular}{|c|c|c|c|c|}
\hline \multirow[t]{2}{*}{ Experiment } & \multicolumn{4}{|c|}{ Location of greater density } \\
\hline & Copepods & Amphipods & Polychaetes & Ostracods \\
\hline \multicolumn{5}{|c|}{ Beginning of experiment } \\
\hline Flounder 4 & Inside $\cdot$ & ns & ns & as \\
\hline Flounder 5 & Outside ${ }^{*}$ & $\mathrm{~ns}$ & ns & Outside " \\
\hline Flounder 6 & $\mathrm{~ns}$ & ns & ns & ns \\
\hline \multicolumn{5}{|c|}{ End of experiment } \\
\hline Flounder 4 & Outside $\cdots$ & ns & ns & Outside . \\
\hline Flounder 5 & Outside ${ }^{*}$ & ns & ns & ns \\
\hline Flounder 6 & Outside $\cdots$ & Outside" & Outside ${ }^{*}$ & ns \\
\hline Goby 1 & ns & ns & ns & ns \\
\hline
\end{tabular}

Table 10. Results of Wilcoxon paired tests comparing densities of prey inside cages at the beginning and end of experiments

\begin{tabular}{|c|c|c|}
\hline $\begin{array}{l}\text { Experiment } \\
\text { Prey }\end{array}$ & $\begin{array}{c}\text { Significance } \\
\text { level }\end{array}$ & $\begin{array}{c}\text { Direction of } \\
\text { change }\end{array}$ \\
\hline \multicolumn{3}{|l|}{ Flounder 4} \\
\hline Copepods & $p<0.001$ & Decrease \\
\hline Amphipods & $p<0.05$ & Decrease \\
\hline Polychaetes & ns & \\
\hline Ostracods & $p<0.001$ & Decrease \\
\hline \multicolumn{3}{|l|}{ Flounder 5} \\
\hline Copepods & ns & \\
\hline Amphipods & ns & \\
\hline Polychaetes & ns & \\
\hline Ostracods & ns & \\
\hline \multicolumn{3}{|l|}{ Flounder 6} \\
\hline Copepods & $\mathrm{p}<0.05$ & Decrease \\
\hline Amphipods & $\mathrm{p}<0.05$ & Increase \\
\hline Polychaetes & ns & \\
\hline Ostracods & ns & \\
\hline \multicolumn{3}{|l|}{ Goby 1} \\
\hline Copepods & ns & \\
\hline Amphipods & ns & \\
\hline Polychaetes & ns & \\
\hline Ostracods & ns & \\
\hline
\end{tabular}

The presence of vegetation enhanced growth rates only for juvenile tautog. For this species, vegetation is an important component of foraging quality. For winter flounder and naked goby, in contrast, vegetation was either inconsequential or a hindrance to growth. A note of caution is warranted regarding the Ulva treatments in growth experiments. Although vegetated and unvegetated habitats were consistent and predictable at the LEH sites, vegetated substrates (Ulva) at the GB sites were variable, requiring addition of macroalgae to the cages to maintain the vegetated experimental treatments. The immediate addition of Ulva presumably included much of the attendant prey species, but might not have adequately duplicated conditions in undisturbed UIva patches. In addition to providing supplemental prey items, Ulva patches could influence prey behavior on the sediments under them. Thus, growth in the Ulva cages in the tautog experiments of 1988 and all of the 1989 experiments may not be representative of natural conditions.

I could not directly compare UIva and Zostera habitats, since they did not co-occur at each site. Because interaction terms in the growth experiment ANOVAs were rarely significant, I conjectured that the contrast between vegetated and unvegetated habitats at each site was not due to the type of vegetation present, allowing a speculative comparison of the 2 vegetation types based on site differences. Growth rates were faster at Ulva-dominated sites for all 3 species. These sites have the advantage of faster growth plus the availability of a predation refuge provided by the macroalgae (Wilson et al. 1989). The trade-off, however, is that Ulva is a highly variable, ephemeral habitat. Eelgrass beds, by comparison, are spatially and temporally stable. Perhaps due to this stability, densities of several other fish species are higher at Zostera sites than Ulva sites (Sogard \& Able 1991).

Food availability has been proposed as one factor accounting for the high densities of fishes and decapods in seagrass beds (Virnstein et al. 1983, Ryer 1987). Results of the growth experiment for Gobiosoma bosci, however, suggest that some fishes actually sacrifice growth potential by residing in grassbeds. High densities of gobies (and potentially other species with 
Table 11. Results of stepwise multiple regressions assessing the relationship of prey densities and sediment size to growth in length for each experiment in 1989. Variables available for entry in each regression were the beginning and ending densities of copepods (Cop. 1 and Cop. 2 respectively) and amphipods (Amph. 1 and Amph. 2) in each cage and the percentage of silt/clay in the sediment (Silt). $F$ values are for final regression equations. Variables included in final regression equations are listed in order of entry, along with the change in $R^{2}$ effected by their entry. A negative sign by a variable indicates a negative relationship with fish growth

\begin{tabular}{|c|c|c|c|c|}
\hline Experiment & $F$ & Final $\mathrm{R}^{2}$ & $\begin{array}{l}\text { Variables } \\
\text { entered }\end{array}$ & $\begin{array}{c}\text { Change } \\
\text { in } R^{2}\end{array}$ \\
\hline Flounder 4 & $6.23^{\circ}$ & 0.229 & Silt $(-)$ & 0.229 \\
\hline Flounder 5 & $9.87^{\cdots}$ & 0.485 & Silt $(-)$ & 0.229 \\
\hline Flounder 6 & $7.24^{\circ}$ & 0.248 & Amph. $1(-)$ & $\begin{array}{l}0.200 \\
0.248\end{array}$ \\
\hline Goby 1 & $11.88^{\cdots} \cdot$ & 0.531 & Amph. 1 & 0.332 \\
\hline
\end{tabular}

similar food requirements) in eelgrass may be due primarily to its function as a refuge.

A parallel pattern occurs in freshwater lakes, where macrovegetation has a poorer foraging value, but provides greater protection from predators (Werner et al. 1983). Juvenile fish concentrate in the vegetated littoral zone to avoid predation risk, resulting in lowered growth rates. With increased size, fish are able to move into more profitable habitats.

\section{Growth experiments - factors influencing growth rates}

For Pseudopleuronectes americanus, growth differences did not appear to be related to prey densities inside the cages. High growth rates at the GB 2 site, where prey densities, especially amphipods, were generally low, resulted in nonsignificant or negative relationships of flounder growth with initial prey densities (Table 11).

I propose that contrasts in water temperatures were influential for winter flounder growth. In New Jersey, Pseudopleuronectes americanus are near the southern limit of their range (Bigelow \& Schroeder 1953). The warmer water temperatures in Little Egg Harbor (Table 3) could have been detrimental to their growth, especially in the late June experiments. Juvenile $P$. americanus tend to avoid high water temperatures (Bigelow \& Schroeder 1953, Pearcy 1962). Increasing water temperatures could also explain the decline in flounder growth over the course of the 3 experiments conducted each year (Fig. 3). Comparable data from higher latitudes would be valuable in determining if winter flounder growth in New Jersey is limited by water temperature.

For this study I conducted only a general analysis of available food, with the goal of distinguishing broadscale differences among the sites and habitats used in caging experiments. Individual prey species were not identified and I did not measure size-frequency distributions of prey. Such information might have strengthened the correspondence of flounder growth with food resources if different species or size classes varied in relative distribution across the estuary and also varied in profitability or accessibility to fish predators.

The significant relationship of Pseudopleuronectes americanus growth with sediment structure may have been related to prey accessibility (Table 11). Faster growth occurred in coarser sediments. Sandier substrates may enable better detection and capture of prey compared to muddier sediments, such as those present at the GB 1 site and inside grassbeds at the LEH sites (Table 2).

Growth rates of Gobiosoma bosci, in contrast to winter flounder, demonstrated a greater degree of correspondence with food availability. The pattern of goby growth among sites and habitats was closely similar to that of Pseudopleuronectes americanus. By the time of the goby experiment, however, amphipod densities at the GB 2 site had increased (Fig. 8), resulting in a significant regression of growth rate on amphipod density. Water temperature did not differ among the 4 sites during the goby experiment (Table 3), and was unlikely to be a causal factor in growth differences.

Temperature and prey density data were not collected during the tautog experiments (in 1988). Assuming similar general patterns between 1989 and 1988, water temperatures at the time tautog experiments were conducted (August and September) should not have differed among sites. Tautog growth was always highest at the GB 1 site, which had the highest prey densities in 1989 sampling. If patterns in prey density were similar in 1988, there may have been a positive correspondence of tautog growth with prey availability.

All 3 species had faster growth rates in Great Bay 
than in Little Egg Harbor (Table 6). Correlational evidence suggested water temperature differences were influential in winter flounder growth and prey density differences were influential in goby and tautog growth. However, other contrasts between the 2 estuaries may have affected growth patterns for all 3 species. A lower tidal range, decreased tidal flushing, and reduced current speeds are probable at the LEH sites, due to their greater distance from Little Egg Inlet and the presence of eelgrass beds. Other potential differences include variables that I did not measure, such as those relating to water quality. Laboratory experiments specifically testing the influence of prey densities and physical parameters would be valuable in determining the hierarchy of factors causing variability in growth.

\section{Potential trade-offs}

If size is crucial to the survival of a small, newly recruited fish, individuals should ideally reside in habitats that maximize the ratio of growth to mortality (Werner \& Gilliam 1984). If fish are not most abundant in habitats with the highest baseline growth rates, compromises are implicated.

Based on throw trap sampling, Pseudopleuronectes americanus densities matched growth patterns. Flounder distribution among the various sites and habitats differed from 1988 to 1989 (Fig. 2), but similar differences were observed in the pattern of growth rates (Fig. 3). Densities were higher at the LEH 2 site than might be expected on the basis of growth rates, but overall trade-offs were not evident. Their ability to bury in sediments (Bigelow \& Schroeder 1953) presumably limits detection by visual predators, allowing flounders to exploit unvegetated habitats that are avoided by other species. Thus, winter flounder need not compromise growth to reduce predation risk.

For juvenile Tautoga onitis, trade-offs were again not apparent. Tautog were collected only from vegetation and primarily from the GB 1 site, where growth was highest. Growth in length was usually higher in vegetation, but growth in weight was higher on bare sand in some cases (Sogard 1990). Thus, the complete absence of tautog in unvegetated habitats may in part be due to predation risk or other unfavorable attributes.

In contrast to Pseudopleuronectes americanus and Tautoga onitis, Gobiosoma bosci demonstrated an obvious trade-off, with the highest natural densities in the poorest habitat for growth (eelgrass). Densities of this species were also higher in vegetation than sand at all 4 sites. Gobies may be dependent on vegetation for other components of habitat quality, such as protection from predators.

\section{Habitat selection patterns}

The density patterns of the 3 species used in this study indicate different patterns of habitat selection. Pseudopleuronectes americanus are better able to exploit sand or mud habitats, due to their cryptic coloration and burying abilities. With this adaptation, they have circumvented the need for vegetation as a predator refuge and avoided potential bottlenecks (sensu Werner \& Gilliam 1984), and are able to exploit areas of better foraging value. Utilization of Ulva habitats similarly provides juvenile Tautoga onitis with an advantage over other species that do not fully exploit this habitat, but tautogs risk the unpredictable disappearance of this ephemeral habitat. Gobiosoma bosci, in contrast, follows the more common pattern of concentration in eelgrass beds, presumably resulting in less than optimal growth rates but enhanced levels of other habitat quality factors in a relatively stable, predictable habitat.

\section{Conclusions}

This study demonstrates that there can be significant variability in short-term growth rates for juvenile fishes across an estuarine nursery. I believe these differences reflect natural variability in baseline habitat quality. The similarity in relative growth differences across a series of experiments indicates that, at least for winter flounder and tautog, contrasts in foraging quality are stable; i.e. favorable locations consistently support faster growth rates.

These results lead to several questions regarding habitat effects on growth and the importance of variability in growth. I did not directly test intraspecific density effects, and interspecific competitors were excluded from cages. Particularly in crowded habitats like eelgrass beds, the presence of competitors should further reduce foraging value. Eelgrass beds might be especially susceptible to competitive bottlenecks (Werner \& Gilliam 1984) during the juvenile stage. In addition to effects on growth from competitors, effects due to predation risk should be evaluated. Based on prior studies using decapods as prey (Heck \& Thoman 1981, Wilson et al. 1987, 1989), I made the assumption that vegetation provides a protective refuge for fishes as well. The actual variation in predation risk incurred by residence in different habitats needs to be verified, however, before conclusions can be drawn about behavioral compromises in habitat selection. Another question of interest is the degree of migration by individual fishes among habitats, among locations in an estuary, or among estuaries. In a prior study (Sogard 1989) I suggested that site fidelity may be low, with a high level of turnover in habitat patches. Obviously, 
individual growth rates would be influenced by the pattern of movement among habitats. Finally, I have placed much emphasis on the importance of rapid growth to the individual, but the actual correspondence of growth rate with survival to later stages is unknown. If rapid growth does indeed translate into higher subsequent survival, it would be valuable to determine when growth variation is most influential (such as the initial post-settlement stage) and the extent to which sizeselective predation accounts for variability in survival.

Acknowledgements. I am indebted to Dan Roelke for his invaluable assistance in field work and laboratory analyses throughout this study. I thank Ken Able, Ken Heck, and Peter Morin for their advice on experimental design and careful reviews of the manuscript. Nathan Able and Leslie Hartman assisted in the field and with processing of meiofauna samples. Kim Wilson contributed constructive ideas on data analysis and interpretation. Funding for this study was provided in part by grants from the Electric Power Research Institute, the National Audubon Society, and the New Jersey Marine Sciences Consortium. This article is Rutgers University Institute of Marine and Coastal Sciences publication no. 92-28.

\section{LITERATURE CITED}

Able, K. W., Wilson, K. A., Heck, K. L. Jr (1989). Fishes of vegetated habitats in New Jersey estuaries: composition, distribution, and abundance based on quantitative sampling. Center for Coastal and Environmental Studies, Rutgers Univ. Publ. 1041, New Brunswick, New Jersey

Adams, S. M. (1976). The ecology of eelgrass, Zostera marina (L. ), fish communities. I. Structural analysis. J exp. mar. Biol. Ecol. 22: 269-291

Bigelow, H. B., Schroeder, W C. (1953). Fishes of the Gulf of Maine. Fish. Bull. U.S. 53: 1-577

Briggs, P. T., O'Connor, J. S. (1971). Comparison of shore-zone fishes over naturally vegetated and sand-filled bottoms in Great South Bay. N. Y. Fish Game J. 18: 25-41

Cerri, R. D., Fraser, D. F. (1983). Predation and risk in foraging minnows: balancing conflicting demands. Am. Nat. 121: $552-561$

Cushing, D. H. (1974). The possible density-dependence of larval mortality and adult mortality in fishes. In: Blaxter, J. H. S. (ed.) The early life history of fish. Springer-Verlag, Berlin, p. 103-112

Day, R. W., Quinn, G. P. (1989). Comparisons of treatments after an analysis of variance in ecology. Ecol. Monogr. 59: $433-463$

Festa, P. J. (1979). Analysis of the fish forage base in the Little Egg Harbor estuary. New Jersey Dept Envir. Protection Tech. Rep. No. 24M

Grover, J. J. (1982). The comparative feeding ecology of five inshore, marine fishes off Long Island, New York. Ph.D. thesis, Rutgers Univ., New Brunswick, New Jersey

Healey, M. C. (1982). Timing and relative intensity of size selective mortality of juvenile chum salmon (Oncorhynchus ketal during early sea life. Can. J. Fish. Aquat. Sci. 39: 952-957

Heck, K. L., Jr, Able, K. W., Fahay, M. P., Roman, C. T (1989). Fishes and decapod crustaceans of Cape Cod eelgrass meadows: species composition and seasonal abundance patterns. Estuaries 12: 59-65
Heck, K. L. Jr, Thoman, T. A. (1981), Experiments on predator-prey interactions in vegetated aquatic habitats. J. exp. mar. Biol. Ecol. 53: 125-134

Houde, E. D. (1987). Fish early life dynamics and recruitment variability. Am. Fish. Soc. Symp. 2: 17-29

Kushlan, J. A. (1981). Sampling characteristics of enclosure throw traps. Trans. Am. Fish. Soc. 110: 557-562

Marshall, N., Lukas, K. (1970). Preliminary observations on the properties of bottom sediments with and without eelgrass, Zostera marina cover. Proc. natn. Shellfish Ass. 60: $107-112$

Milinski, M., Heller, R. (1978). Influence of a predator on the optimal foraging behaviour of sticklebacks (Gasterosteus aculeatus L.). Nature, Lond. 275: 642-644

Mittelbach, G. G. (1988). Competition among refuging sunfishes and effects of fish density on littoral zone invertebrates. Ecology 69: 614-623

Nero, L. L. (1976). The natural history of the naked goby Gobiosoma bosci (Perciformes: Gobiidae). M.Sc. thesis, Old Dominion Univ., Norfolk, Virginia

Orth, R. J., Heck, K. L. Jr (1980). Structural components of eelgrass (Zostera marina) meadows in the lower Chesapeake Bay - Fishes. Esluaries 3: 278-288

Parker, R. R. (1971). Size selective predation among juvenile salmonid fishes in a British Columbia inlet. J. Fish. Res. Bd Can. 28: 1503-1510

Pearcy, W. G. (1962). Ecology of an estuarine population of winter flounder, Pseudopleuronectes amenicanus (Walbaum). Parts I-IV Bull. Bingham Oceanogr Coll. 18: 1-78

Pihl, L., Rosenberg, R. (1982). Production, abundance, and biomass of mobile epibenthic marine fauna in shallow waters, western Sweden. J. exp. mar. Biol. Ecol. 57: 273-301

Post, J R., Evans, D. O. (1989a). Experimental evidence of size-dependent predation mortality in juvenile yellow perch. Can. J. Zool. 67: 521-523

Post, J. R., Evans, D. O. (1989b). Size-dependent overwinter mortality of young-of-the-year yellow perch (Perca flavescens): laboratory, in situ enclosure, and field experiments. Can. J. Fish. Aquat. Sci. 46: 1958-1968

Power, M. E. (1984). Depth distributions of armored catfish: predator induced resource avoidance? Ecology 65: 523-528

Rozas, L. P., Odum, W. E. (1988). Occupation of submerged aquatic vegetation by fishes: testing the roles of food and refuge. Oecologia 77: 101-106

Ryer, C. H. (1987). Temporal patterns of feeding by blue crabs (Callinectes sapidus) in a tidal-marsh creek and adjacent seagrass meadow in the lower Chesapeake Bay. Estuaries 10: $136-140$

Schmitt, R. J., Holbrook, S. J. (1985). Patch selection by juvenile black surfperch (Embiotocidae) under variable risk: interactive influence of fond quality and structural complexity. J. exp. mar Biol. Ecol. 79: 39-64

Snedecor, G. W. Cochran, W. G. (1980). Statistical methods, 7 th edn. Iowa State University Press, Ames

Sogard, S. M. (1989). Colonization of artificial seagrass by fishes and decapod crustaceans: importance of proximity to natural eelgrass. J. exp. mar. Biol. Ecol. 133: 15-37

Sogard, S. M. (1990). Parameters of habitat quality for epibenthic fishes and decapod crustaceans in New Jersey estuaries. Ph.D thesis, Rutgers Univ. New Brunswick, New Jersey

Sogard, S. M., Able, K. W. (1991). A comparison of eelgrass sea lettuce macroalgae, and marsh creeks as habitat for epibenthic fishes and decapods. Estuar. coast. Shelf Sci. 33: 501-519

Sogard, S. M., Able, K. W (in press). Growth variation of newly settled winter flounder (Pseudopleuronectes 
americanus) in New Jersey estuaries as determined by otolith microstructure. Neth. J. Sea Res.

Sogard, S. M., Able, K. W., Fahay, M. P. (in press). Early life history of the tautog. Tautoga onitis, in the Mid-Atlantic Bight. Fish. Bull. U.S.

Virnstein, R. W., Mikkelsen, P. S., Cairns, K. D., Capone, M. A. (1983). Seagrass beds versus sand bottoms: the trophic importance of their associated benthic invertebrates. Fla Scient. 46: 363-381

Weinstein, M. P., Brooks, H. A. (1983). Comparative ecology of nekton residing in a tidal creek and adjacent seagrass meadow: community composition and structure. Mar. Ecol. Prog. Ser 12: 15-27

This article was presented by K. L. Heck, Jr, Dauphin Island, Alabama, USA
Werner, E. E., Gilliam, J. F. (1984). The ontogenetic niche and species interactions in size-structured populations. A. Rev. Ecol. Syst. 15: 393-425

Werner, E. E., Gilliam, J. F., Hall, D. J., Mittelbach, G. G. (1983). An experimental test of the effects of predation risk on habitat use in fish. Ecology 64: 1540-1548

Wilson, K. A., Able, K. W., Heck, K. L. Jr (1989). Predation rates on juvenile blue crabs in estuarine nursery habitats: evidence for the importance of macroalgae (Ulva lactuca). Mar. Ecol. Prog. Ser. 58: 243-251

Wilson, K. A., Heck, K. L. Jr, Able, K. W. (1987). Juvenile blue crab, Callinectes sapidus, survival: an evaluation of eelgrass, Zostera marina, as refuge. Fish. Bull. U.S. 85: 53-58

Manuscript first received: September 6, 1991 Revised version accepted: June 11, 1992 